\title{
Refugees, expellees and immigrants: comparing migrant reception policies and practices in post-war Bristol, Dortmund and Malmö
}

\author{
Brian Shaev ${ }^{1 \star}$ (D), Sarah Hackett ${ }^{2}$, Pål Brunnström ${ }^{3}$ and Robert Nilsson Mohammadi ${ }^{4}$ \\ ${ }^{1}$ Institute for History, Leiden University, The Netherlands, ${ }^{2}$ (retired) History and Heritage/School of \\ Humanities and Cultural Industries, Bath Spa University, Bath, UK, ${ }^{3}$ Department of Urban Studies, Malmö \\ University, 20506 Malmö, Sweden and ${ }^{4}$ Department of Society, Culture and Individuality, Malmö \\ University, 20506 Malmö, Sweden \\ ${ }^{*}$ Corresponding author. Email: b.shaev@hum.leidenuniv.nl
}

\begin{abstract}
The vital role that cities play in the governance of migration is increasingly recognized, yet migration scholars still perceive this 'local turn' as a recent phenomenon. This article presents a cross-country and cross-city comparative analysis of three mid-size European cities during the post-war period: Bristol, Dortmund and Malmö. It analyses administrative cultures and local policy arenas, exposing the complexity of local migration policy-making and the crucial importance of historical perspectives. It reveals the inherent local variation in policies and practices, and argues that traditional national-level studies do not fully capture how urban actors responded to migration.
\end{abstract}

\section{Introduction}

Migration studies in Europe have taken a sharp 'local turn' in recent years, as scholars increasingly appreciate how local settings shape and foster the reception and integration of migrants. Cities are, as Peter Scholten writes, 'the hotspots of migration and diversity... where most migrants arrive, where they settle, go to school, find jobs, interact with others. ${ }^{1}$ Studies across a range of disciplines have gone some way towards showcasing how migrant communities have shaped and transformed their urban surroundings, and how cities have responded to the challenges and opportunities presented by migration. ${ }^{2}$ Moving beyond what Andreas Wimmer and Nina Glick Schiller termed 'methodological nationalism', ${ }^{3}$ they have reminded us that there exists a local dimension to migration and diversity that has frequently

\footnotetext{
${ }^{1}$ P. Scholten, 'Migration, history and urban life', in T. Caponio, P. Scholten and R. Zapata-Barrero (eds.), The Routledge Handbook of the Governance of Migration and Diversity in Cities (Abingdon, 2019), 9.

${ }^{2}$ P. Ireland, Becoming Europe: Immigration, Integration, and the Welfare State (Pittsburgh, 2004); T. Caponio and M. Borkert (eds.), The Local Dimension of Migration Policymaking (Amsterdam, 2010); N.G. Schiller and A. Çağlar (eds.), Locating Migration: Rescaling Cities and Migrants (Ithaca, 2011).

${ }^{3}$ A. Wimmer and N.G. Schiller, 'Methodological nationalism and beyond: nation-state building, migration and the social sciences', Global Networks, 2 (2002), 301-34.

(c) The Author(s), 2022. Published by Cambridge University Press. This is an Open Access article, distributed under the terms of the Creative Commons Attribution licence (https://creativecommons.org/licenses/by/4.0/), which permits unrestricted re-use, distribution, and reproduction in any medium, provided the original work is properly cited.
} 
been overlooked, and that a city lens can lead to a more precise and multifaceted study of the migration process. ${ }^{4}$

Although often lacking a historical perspective, an important theme that has emerged from this scholarship is the important part the city level plays in devising and implementing migration, integration and diversity policies. Indeed, though migration and immigrant admissions policies are the responsibility of national governments, there is an increasing recognition that their immediate consequences 'are shouldered by local governments'. ${ }^{5}$ Rather than just perceiving cities to be the spaces in which migrants often settle and live, their authorities are increasingly understood as active agents in the migration and integration process, and as having the potential to pursue distinctly local approaches and strategies. ${ }^{6}$ The 'local turn' has led scholars to examine urban contexts anew, though this has been largely limited to migration in contemporary urban societies, leaving an impression that local autonomy and policies are recent inventions. Sociology and political science interest in migration in Europe, born amidst societal concerns about post-colonial and guest-worker migration in the 1970s, has neglected preceding migrations in the post-war period, especially of refugees, displaced persons, as well as labour migrants. Implicit is a hard break between post-war migrations in the 1940s-50s, presented as relatively tranquil after the initial crisis of displaced persons had passed by the early 1950s, and a stormier period in the 1960s-70s.

This article presents a cross-country, cross-city historical comparison that explores the linkages between the immediate post-war period and new forms of migration in the 1950s-60s. As we argue elsewhere, urban histories capture greater diversity in migration policy-making, while also opening doors to more multidirectional, rather than exclusively top-down, narratives of local, regional and national history. ${ }^{7}$ The rewards of local approaches to migration history are demonstrated by Mark Spicka's investigation of Stuttgart, where local officials developed 'integrationist' policies towards guest workers already in the 1960s despite an absence of federal support, and by Emile Chabal's study of local clientelism in the governance of 'minority politics' in Montpellier. ${ }^{8}$ Building on these histories, we argue urban histories of migration would benefit from comparative analysis. We draw

\footnotetext{
${ }^{4}$ N. Foner, J. Rath, J.W. Duyvendak and R. van Reekum (eds.), New York and Amsterdam: Immigration and the New Urban Landscape (New York, 2014); A. Çağlar and N.G. Schiller, Migrants and City-Making: Dispossession, Displacement, and Urban Regeneration (Durham, NC, 2018).

${ }^{5}$ R. Penninx, K. Kraal, M. Martiniello and S. Vertovec, 'Introduction: European cities and their new residents', in R. Penninx, K. Kraal, M. Martiniello and S. Vertovec (eds.), Citizenship in European Cities: Immigrants, Local Politics and Integration Policies (Abingdon, 2016), 5.

${ }^{6} \mathrm{E}$. de Graauw and F. Vermeulen, 'Cities and the politics of immigrant integration: a comparison of Berlin, Amsterdam, New York City and San Francisco', Journal of Ethnic and Migration Studies, 42 (2016), 989-1012; S. Hackett, "The "local turn" in historical perspective: two city case studies in Britain and Germany', International Review of Administrative Sciences, 83 (2017), 340-57.

${ }^{7}$ S. Hackett, B. Shaev, P. Brunnström and R. Nilsson Mohammadi, 'Variants, race relations, and trend-setters: postwar Dortmund, Bristol and Malmö in national migration histories', in C. Cornelissen, B. Kümin and M. Rosprocher (eds.), Migration and the European City: Social and Cultural Perspectives from the Early Modern to the Present (forthcoming).

${ }^{8} \mathrm{E}$. Chabal, 'Managing the postcolony: minority politics in Montpellier, c. 1960-2010', Contemporary European History, 23 (2014), 237-58; M. Spicka, 'City policy and guest workers in Stuttgart, 1955-1973', German History, 31 (2013), 345-65.
} 
inspiration from Bettina Severin-Barboutie's comparative history of Lyon and Stuttgart in the 1940s-80s, and Sarah Hackett's comparison of Muslim migrants in Bremen and Newcastle upon Tyne in the fields of education, employment and housing. ${ }^{9}$ Whereas Severin-Barboutie investigates migrants' experiences, and Hackett focuses on the 1960s-2000s, we offer a pioneering comparison of urban policy-making in the post-war era.

Our comparative history shows that, in stark contrast to the tranquil perception of the pre-1970 period, migration was a conflictual subject in local settings, and cities formulated policies and practices to address it earlier than most scholarship acknowledges. Following an insight from Michael Alexander, our comparative methodology expects that different cities will focus on different dimensions of policy responses to migration, and therefore we must compare across policy domains rather than simply within one or more policy domain(s) to capture the diversity in city strategies. ${ }^{10}$ To do so, we compare three mid-size cities whose migrant reception policies and practices of the 1940s-60s remain largely unexplored, especially in comparative perspective: Bristol, Dortmund and Malmö. They all experienced de-industrialization to varying extents and were home to local governments that were either dominated by social democrats or often had centre-left leanings across the post-war years. Furthermore, all three witnessed the arrival of migrants in greater numbers and from new backgrounds in the post-war era, posing new opportunities and challenges for local policy-makers. An examinination of these cities shifts the study of migration beyond gateway cities, ${ }^{11}$ while enabling comparative insights into the factors that shaped urban reception and integration policies and practices. It also reveals how and why municipalities, and other local-level actors, reacted to the settlement and integration of migrant communities at different times in the post-war period.

To carry out this international comparison, we employ three concepts prominent in the 'local turn' in migration studies: local policy arena, administrative culture and local governance. 'Local policy arena' comprises the municipal setting and relevant policy actors, the most important of whom, following Tiziana Caponio, are elected politicians, urban bureaucrats and civil society. ${ }^{12}$ 'Administrative culture' is the 'prevailing attitude' and worldviews of bureaucrats within a local policy arena, their relations with elected leaders and semi- and non-state actors including refugee and migrant councils, and the ways their understandings of city history and identity affect how they conceptualize local migration. ${ }^{13}$ Finally, governance is the mode of interaction between the relevant actors within a local policy arena in which

\footnotetext{
${ }^{9}$ B. Severin-Barboutie, Migration als Bewegung am Beispiel der Städte Stuttgart und Lyon nach 1945 (Tübingen, 2019); S. Hackett, Foreigners, Minorities and Integration: The Muslim Immigrant Experience in Britain and Germany (Manchester, 2013).

${ }^{10} \mathrm{M}$. Alexander, 'Local policies towards migrants as an expression of Host-Stranger relations: a proposed typology', Journal of Ethnic and Migration Studies, 29 (2003), 411-30, at 425.

${ }^{11} \mathrm{M}$. Alexander, Cities and Labour Immigration: Comparing Policy Responses in Amsterdam, Paris, Rome and Tel Aviv (Ashgate, 2007); P. Panayi, Migrant City: A New History of London (New Haven, 2020).

${ }^{12} \mathrm{~T}$. Caponio, 'Conclusion: making sense of local migration policy arenas', in Caponio and Borkert (eds.), The Local Dimension, 161-95.

${ }^{13}$ Caponio, 'Conclusion'; Alexander, 'Local policies towards migrants as an expression of Host-Stranger relations'.
} 
administrative culture feeds into city officials' interactions with local, state and national actors: it is the interactive process through which policies emerge, resulting in local responses that range from inaction to concrete policies implemented by specific actors. ${ }^{14}$

The article is structured to highlight the rich history of city interactions in each urban case-study, before bringing them together in comparative analysis. It begins with sections on Dortmund, Bristol and Malmö, respectively, and culminates in a comparative section in which we investigate local governance by exploring first the impact of city histories and identities on administrative cultures of migration; and secondly horizontal interactions in local policy arenas and vertical interactions of cities with state and national contexts. The comparison reveals how municipalities and local-level actors responded to the arrival and settlement of migrant communities, as well as the inherent local variation in policies and practices that emerged across these three urban contexts. Though there was in effect a 'local turn' in each city, the diverse responses each deployed - which ranged from welcoming to stigmatizing migrants - can be traced to divergences in how local narratives of city history and concepts of city identity intersected with national and local policy-making and new forms of urban migration.

\section{Dortmund}

In 1948, Westfalenpost, a regional newspaper, ran an article titled 'People in the melting pot of the Ruhr. ${ }^{15}$ Quoting a local demographer, it claimed that, due to mass immigration in the late nineteenth century, Ruhr inhabitants were 'not "burdened" by tradition but rather made up their own type'. The arrival of mostly Polish migrants before World War I (many of whom re-emigrated during the interwar period) had been a considerable source of local anxiety but, as this quote suggests, it became valorized as a point of pride after World War II. The Ruhr's postwar self-identity as a 'melting pot' bound by migratory links from East to West was to prove integral to the formulation of migration discourses in Dortmund, the Ruhr's largest city. Dortmund's administrative culture, marked by a tight interlocking of the city council and administration, exercised particular importance for migrants' reception. Mobilizing histories of Eastern German and Polish migration to Dortmund, city leaders and officials presented the arrival of expellees almost as a homecoming. The overarching narrative of a migration city then extended to Soviet-Zone refugees who arrived in mass in the early 1950s and for guest workers in the 1960s. The 'melting-pot' metaphor gave discursive cohesion to city efforts to build a community of suffering among locals, expellees and refugees to lessen intercommunity tensions during Dortmund's reconstruction.

Dortmund emerged from World War II in profound crisis, with 40-60 per cent of its housing stock destroyed, a 'hungry winter' in 1946/47 that was especially terrible in the Ruhr, and severe population displacement. Even with economic boom

\footnotetext{
${ }^{14}$ T. Caponio, P. Scholten and R. Zapata-Barrero, 'Introduction: the governance of migration and diversity in cities', in Caponio, Scholten and Zapata-Barrero (eds.), The Routledge Handbook, 6.

${ }^{15 ،}$ 'Gesicherter aus zwei Himmelsrichtungen: Menschen im Schmelztiegel des Ruhrgebietes', Westfalenpost, 11 Jan. 1948.
} 
and full employment in the 1950s, the housing crisis persisted as tens of thousands of expellees and refugees continued to arrive every year. The city's rhetoric tying past migration to the present crisis had a distinctly social democratic hue reflecting the hegemony of the Social Democratic Party (SPD) in post-war Dortmund, where it dominated the city council and administration. Social democratic leaders tied a welcoming discourse to one of mutual obligation that exhorted incoming migrants to show solidarity with the local population's suffering, in particular with evacuees who were banned from returning to Dortmund due to shortages. Dortmund's post-war mayor, Fritz Henssler, told the city council in 1951 that 'I consider it selfunderstood that Dortmund will do its share to build a feeling of home for the expellees and repressed', but warned against 'play[ing] these victims against each other [such] that some gain the feeling that they are less worthy of rights and care than others'. ${ }^{16}$ This discourse of mutual obligation continued with Henssler's successor, Mayor Dieter Keuning. ${ }^{17}$ Expellees, refugees and locals - everybody was deserving of solidarity and municipal aid in Dortmund's official discourse.

Friendly relations between the largest parties fostered consensus on Dortmund's city council. It helped that Henssler asked the head of the local Christian Democratic Union (CDU), Willi Koch, an advisory expellee councillor, to chair the city council's Expellee and Refugee Council in 1949 as the city emerged from British occupation. ${ }^{18}$ Koch shared the city's objective of mitigating intercommunity tensions, for instance by asking that the Advisory Expellee Council emphasize the burden-sharing law's benefits for locals and not just for expellees. ${ }^{19}$ A CDU-SPD consensus comes out clearly in their annoyed dismissal of local Communist efforts to stigmatize Soviet-Zone refugees. In 1953, at the height of the violently repressed East Berlin uprising, a Communist councillor said that 'There is rising discontent among the people and the old refugees about these so-called new Eastern-Zone refugees and one asks, why are they handled with special and privileged care? It must be said that for many Eastern-Zone refugees there was not any necessity to leave their home. ${ }^{, 20} \mathrm{CDU}$ and SPD councillors took turns slamming these comments, with an SPD councillor replying, 'A word to the [Communists]: It would be welcome if you would stop saying that these people could have remained home. It is a sad sign that if people have different opinions from others that they must emigrate.' The council approved subsidies for Soviet-Zone refugees' care and housing against Communist votes in the city's largest political controversy on migration in the 1950s.

The city manager and archivist consciously mobilized Dortmund's immigration history during its rapid late nineteenth-century industrialization to solidify a postwar identity as a migration city. The city archivist was particularly important for memory politics in Dortmund, charged as he was with Waldenburg's Patenschaft, its public memory archive. The narrative shaped Dortmund's administrative culture. It had a particularist quality in fostering a myth of brotherhood

\footnotetext{
${ }^{16}$ Stadtarchiv Dortmund (SD), 90/01 2/2, Niederschrift über die Ratsversammlung, 28 and 29 May 1951.

${ }^{17}$ 'Vertriebene sollen sich mit Einheimische verbrüdern', Verwaltungsbericht, 16 Sep. 1955.

${ }^{18} \mathrm{SD}, 100 / 02$, Niederschrift über die parlamentarische Flüchtlingsausschusssitzung, 20 Jan. 1949.

${ }^{19}$ Westfälisches Wirtschaftsarchiv (WW), K1 30.151, Niederschrift über die Sitzung der Vertriebenenbeirates in Dortmund, 19 Oct. 1953.

${ }^{20} \mathrm{SD}, 90 / 01$ 2/3, Niederschrift über die öffentliche Sitzung der Ratsversammlung, 16 Jun. 1953.
} 
between Waldenburg, the origin of Dortmund's principal expellee community, and Dortmund, where a settlement of Waldenburg miners had moved in 1869 to work in Dortmund's mines. ${ }^{21}$ Social democratic discourses centred around working-class solidarity, specifically trade-union solidarity in coal mining. ${ }^{22}$ They were also generalizable. In 1949-51, a new settlement financed by federal and Marshall Plan funds opened in Eving, a Dortmund suburb. The city bulletin took a different but no less generous lesson from history for this community of 900 Poles and Eastern Europeans, promising their 'integration into the civic life of Germans' but 'without the once so-beloved "Germanization" being attempted again'. Local neighbours appear to have been less kind: they commonly referred to the settlement as 'Little-Korea', a reference to its construction during the Korean War, and kept a cold distance from the new arrivals. ${ }^{24}$

Dortmund's Expellee and Refugee Advisory Council hosted city officials and protested refugee conditions, in particular with regard to housing. Paul Klambt, formerly SPD leader on Waldenburg City Council, led the council from 1947 to 1962. He wielded impressive sway, using his social capital as 'father of the refugees' to press the expellees' cause to city leaders, but also to defend the city. ${ }^{25}$ Through him, social democratic discourses gained a foothold in the expellee council, as Klambt regularly referenced the difficulties of local Dortmunders to argue that the city was doing its best under dire circumstances. There were tensions, though, between the council and city. Dortmund's administrative culture expressed a 'traditional' social democratic reticence against encouraging ethnic or communitarian particularism, a finding that Patrick Ireland identifies in neighbouring social democratic-led Essen in later decades as well. ${ }^{26}$ City officials refused, for example, advisory council requests to create a separate Expellee Office or to establish a refugee cultural committee on the city council. ${ }^{27}$ Its goal was expellee and refugee integration into existing organizations, e.g., the chamber of commerce and the municipally owned Sparkassen bank. ${ }^{28}$ The city appears to have worked seamlessly with local Christian charities, entrusting them with the reception of unaccompanied expellee and refugee youth, and promoting 'spiritual care'. ${ }^{29}$ Dortmund's Finance Office also worked with youth charities to build a shelter in Eving for 'homeless foreigners' named the 'House for Everyone. ${ }^{30}$

\footnotetext{
${ }^{21}$ Swientek, '18.000 Waldenburger kamen neu in die Bundesrepublik', Verwaltungsbericht, 29 Aug. 1958.

${ }^{22}$ Swientek, '8. Waldenburger Heimattreffen', Verwaltungsbericht, 24 Aug. 1962.

${ }^{23 ،}$ Ausländer finden neue Heimat', Verwaltungsbericht, 5 Oct. 1951.

${ }^{24}$ Evinger Geschichtsverein, 'Zwischen Ungewissheit und Zuversicht', June 2019, http://geschichtsund kulturverein-eving.de/index.php/der-verein/6-nachruf-wagner.html, accessed 13 Feb. 2021.

${ }^{25}$ SD, 100/02, for instance, Niederschrift über die Sitzung des Flüchtlingsbeirates, 3 Oct. 1949.

${ }^{26}$ Ireland, Becoming Europe, 63-74.

${ }^{27}$ SD, 91/006 5, Niederschrift über die Sitzung des Kulturausschusses, 24 Apr. 1951; SD, 100/02, Niederschrift über die Sitzung des Vertriebenenbeirates der Stadt Dortmund, 27 Apr. 1951.

${ }^{28}$ SD, K1 30.151, Niederschift über die Sitzung des Vertriebenenbeirates in Dortmund, 25 Feb. 1954; WW, K1 30.150, Vereinigung der Industrie- und Handelskammern des Landes Nordrhein-Westfalen. An die Industrie- und Handelskammer zu Dortmund, 30 Nov. 1950.

${ }^{29} \mathrm{~N} 100$ Arbeitsämter, Agenturen für Arbeit, Arbeitsämter Nr. 830, Dr Kliemt, Sozialamt, Jugendamt to Herrn Direktor des Arbeitsamtes, 22 Mar. 1954.

${ }^{30}$ Landesarchiv Nordrhein Westfalen, L 001 Nr. 5288, Friedhofen, Finanzbauamt Dortmund, 30 Apr. 1954 .
} 
In an oral history in the 1970s, Alexander von Plato found that expellees and refugees were central to the Ruhr's post-war 'social-democratization', which 'served again as a melting pot for natives and diverse ethnic and social groups' ${ }^{31}$ We have seen how Dortmund's social democratic leaders consciously propagated this welcoming migration narrative. Further, we can trace continuities - and some discontinuities - in Dortmund's political and administrative culture of migrant reception into the early guest-worker period. In 1960, Greek workers arrived, followed by Spanish and Italian and later Turkish workers. City officials took initiatives to translate municipal service documents, arrange weekly consultation hours at the Sparkassen to assist guest workers in their own languages, organize classes in Italian for guest-worker children and buy books and films for recreational purposes. $^{32}$ City officials were concerned, though, that guest workers would return from vacation with family members, thereby exacerbating housing shortages made worse by cuts in state and federal housing assistance in the early 1960s. ${ }^{33}$ This view partly reflected continuities with post-war-era administrative thinking, when city officials initially demanded that labour recruits from refugee camps should not bring family members with them to Dortmund.

Three incidents in 1965 highlight further continuities in municipal practices and narratives. Firstly, at the opening of the city's first Turkish recreational centre, co-financed by Arbeiterwohlfahrt, an SPD-aligned welfare association, local speakers emphasized that 'This room should serve to foster contacts among [Turks] but also with German work colleagues', and 'the meeting place should serve all communities'. ${ }^{34}$ A Bonn representative warned of cultural alienation and reminded Turkish workers that they were supposed to eventually return to Turkey, but Dortmund officials refrained from making such remarks. Secondly, visiting Nuremberg officials noted with dismay the casualness with which Dortmund officials provided workpapers for foreigners who arrived on tourist visas, a liberalism in line with post-war municipal practices to integrate 'illegal border crossers' from the Eastern Zone into Dortmund's labour market despite their lack of legal documents. ${ }^{35}$ Thirdly, there was a city council controversy in 1965 after a Christian Democrat spoke of 'an excessive number of foreigners in certain occupations in Dortmund'. SPD councillor and future mayor Günter Samtlebe responded by extending city narratives to guest workers, telling the council that in his view there is no danger... [because] the Ruhr has proven itself in its past to be the melting pot of all European peoples'. ${ }^{36}$

\footnotetext{
${ }^{31}$ A. von Plato, 'Fremde Heimat. Zur Integration von Flüchtlingen und Einheimischen in die Neue Zeit', in L. Niethammer and A. von Plato (eds.), 'Wir kriegen jetzt andere Zeiten.' Auf der Suche nach der Erfahrung des Volkes in nachfaschistischen Ländern (Bonn, 1985), 208-13.

${ }^{32 ،}$ 'Unterricht für italienischer Schulkinder', Verwaltungsbericht, 8 Jun. 1962; 'Filmische Betreuung der italienische Gastarbeiter', Verwaltungsbericht, 27 Jun. 1962.

${ }^{33 ،}$ 'Ausländische Arbeitskräfte kehren nach Urlaub zurück', Verwaltungsbericht, 10 Nov. 1961.

${ }^{34}$ 'Begegnungsstätte für Türken und Dortmunder', Verwaltungsbericht, 24 Dec. 1965.

${ }^{35}$ M. Mattes, 'Wirtschaftliche Rekonstruktion in der Bundesrepublik Deutschland und grenzüberschreitende Arbeitsmigration von den 1950er bis zu den 1970er Jahren', in J. Oltmer (ed.), Handbuch Stadt und Migration in Deutschland seit 17. Jahrhundert (Oldenbourg, 2016), 839-40.

${ }^{36}$ SD, 90/01 11, Niederschrift über die 5. Sitzung des Rates der Stadt am Montag, 22 Feb. 1965.
} 
This attitude surfaced again in the initial municipal reaction to the 1966/67 recession, which accelerated a wrenching decades-long de-industrialization of the Ruhr's economy. Foreign workers in Dortmund were particularly affected: their numbers fell by an estimated 40 per cent from 24,000 in 1965 to 14,000 in 1967. ${ }^{37}$ In 1967, an estimated 10 per cent of those receiving unemployment assistance in Dortmund were guest workers, disproportionately high compared to their share of the population. In this disturbing context, a regional conference of employers, trade unions and local labour and social affairs officials met to discuss the vulnerable position of guest workers. They agreed to oppose 'administrative force' in denying workpaper renewals and 'appealed to the public to also treat foreign workers with understanding during this hard period of transition'. ${ }^{38}$ Shortly thereafter, Dortmund's Labour Office director followed up by warning against 'too lightly gambling away' guest workers' potential during the crisis. 'We have the intention', he said, 'to maintain a feeling of security for foreigners who stay here as long as they have their family here, participate in vocational training, or have suffered a work accident. ${ }^{39}$ As the Ruhr entered a troubled new era in the late 1960s, Dortmund authorities took a humane stance on the plight of guest workers that was in line with its reconstruction-era policies towards expellees and refugees.

\section{Bristol}

Bristol witnessed the settlement of various refugee and immigrant groups across the post-World War II years and, in many ways, it evolved as a somewhat hesitant and reluctant migration city. European Voluntary Workers (EVWs) came to the area during the late 1940s, some of whom were Polish. Many worked in local hospitals. ${ }^{40}$ From the early 1950s, Displaced Persons (DPs), especially Estonians, Hungarians and Latvians, arrived from across Europe. Some were aged and in poor health, lived in lodgings and depended on voluntary and charitable assistance. ${ }^{41}$ Other migrant groups included the Chinese, Irish, Italians, Cypriots and Somalis. ${ }^{42}$ Many post-war immigrants were citizens of British colonies or Commonwealth countries, in particular the West Indies, India and Pakistan. Immigrants often found work as nurses, orderlies and domestics in hospitals, or secured semi- and unskilled jobs in domestic services, factories, building and catering, and others suffered from unemployment. ${ }^{43}$ Many of the West Indians especially initially became

\footnotetext{
${ }^{37}$ SD, 90/01 15, Rede des Oberstadtdirektors H.D. Imhoff zum Haushaltsplan 1970 in der Sitzung des Rates am 15.12.1969.

${ }^{38}$ 'Die ausländische Arbeitnehmer auf dem veränderten Arbeitsmarkt', Verwaltungsbericht, 3 Feb. 1967.

${ }^{39}$ 'Beratungsstelle für ausländische Kunden bei der Stadtssparkasse: Arbeitsamt berichtet über Gastarbeitersituation', Verwaltungsbericht, 10 Mar. 1967.

${ }^{40}$ Bristol Archives (BA), Bristol Council of Christian Churches: minutes 1947-55 43077/M/1/2, meeting of the ad hoc committee appointed to deal with the question of European Voluntary Workers, 5 Nov. 1948.

${ }^{41} \mathrm{BA}$, Records of the Bristol (and West) Council for Aid to Refugees: Annual Reports (printed), 1951/ 52-1964/65 27155/2, various; BA, Records of the Bristol (and West) Council for Aid to Refugees: file of correspondence etc., c. 1964-67 27155/3, various.

${ }^{42}$ M. Dresser and P. Fleming, Bristol: Ethnic Minorities and the City 1000-2001 (Chichester, 2007), 144, $159,210$.

${ }^{43}$ Modern Records Unit (MRU), town clerk files, correspondence re the welfare of coloured people 3402 c, second report of the colonial liaison officer, 1 Apr. 1957-30 Sep. 1958, to Committee for the
} 
residentially concentrated in Bristol's so-called inner-city twilight areas, such as St Paul's, an area that quickly became associated with crime, disease, drugs, overcrowding, poor-quality housing, prostitution, social decay and violence. It saw a riot eventually break out in 1980 due to unemployment, disadvantage and tension between the black community and the police. Bristol has a long history as a port and international trading centre, and has been home to a small black community for over four centuries. Yet contrary to what one might expect, so-called 'coloured' immigrants from the West Indies, especially those who arrived after 1945, were not necessarily met with a sense of cosmopolitanism, but rather were frequently perceived as constituting an entirely new, unprecedented, and even disruptive, development.

A complex range of local actors responded to the arrival and settlement of migrant communities, frequently with some unease. Even the city council, which was Labour-controlled for much of the post-war period, arguably did not do enough to promote positive race relations and integration. The conditions encountered by the EVWs and DPs appear to have been more positive than those of South Asians and West Indians. This was likely because they arrived in Bristol through official schemes, were perceived to be in desperate need and deserving of support, and did not carry the same negative connotations as their 'coloured' counterparts. By contrast, Commonwealth immigrants, and West Indians especially, were frequently victims of a race-based mindset that depicted them as morally inferior and alien to the city, and as posing a challenge to the assimilation process. The extent to which racial discrimination existed was perhaps best captured in the colour bar imposed at the state-owned Bristol Omnibus Company. No doubt rooted in racism, but also in the fact that immigrant labour was seen as posing a threat to the availability of work and earnings, the Passenger Group of the Transport and General Workers' Union passed a resolution in 1955 that 'coloured' workers should not be employed as bus crews.

Initially, an assortment of largely charitable, community, religious and voluntary organizations drove the city's response to migrant and refugee groups. EVWs' reception was at least partly managed by an ad hoc committee, which drew upon numerous local organizations for help. These included churches, which were seen as vital in offering friendship and promoting workers' integration, and the YMCA and the Local Education Authority, which provided hostel accommodation and worked to arrange educational courses respectively. ${ }^{44}$ Two active organizations were the Bristol Council of Social Service and the Bristol Council of Christian Churches. They sponsored and supported the work of the Bristol (and West) Council for Aid to Refugees, established in $1951 .^{45}$ In response to the British government's decision to take in some so-called hard-core DPs who, due to their age or poor health, were unable to utilize other immigration schemes, the council

Welfare of Colonial Workers in Bristol; BA, reports of the medical officer of health (including reports of school and port medical officer of health) 1965-67 33416/31a, the medical officer of health, 'The health of Bristol in 1965'.

${ }^{44} \mathrm{BA}, 43077 / \mathrm{M} / 1 / 2$, meeting of the ad hoc committee appointed to deal with the question of European Voluntary Workers, 5 Nov. 1948.

${ }^{45}$ The council benefited from the advice and assistance of its parent body, the British Council for Aid to Refugees. 
purchased a hostel to house refugees. It also helped refugees secure accommodation, donated funds to support university bursaries for Hungarian students and was key to the formation of a Refugee Co-ordinating Committee in the city. Various other organizations also contributed to refugees' welfare during the 1950s and 1960s, including the Federation of Community Centres, the Presbyterian Church and the Women's Voluntary Service. ${ }^{46}$

Bristol's local stakeholders' approach to Commonwealth immigrants was more mixed and, at times, less sympathetic. The city's Indians, Pakistanis and West Indians were frequently associated with overcrowded and poor housing, low social standards, poor English-language and parenting skills and employment opportunities. Bristol's police force actively participated in deliberations on the West Indian community in particular. Whilst acknowledging that most Commonwealth immigrants were 'respectable' and 'hard working', it also conveyed some anxiety about 'coloured' immigrants' integration and residential segregation, and the perceived deterioration of certain neighbourhoods in which they lived. ${ }^{47}$ It expressed concern over cohabitation, illegitimacy, venereal diseases, drug possession and brothelkeeping, and, as a 1962 chief superintendent report stated, the notion that 'coloured persons do not conform to the same moral code as the white community'. ${ }^{48}$ Similarly, a number of Bristol Constabulary's superintendents insisted that legislation against racial discrimination in public places should not be introduced. In the words of one, 'it would give the coloured population a false sense of elevation and power', rather than enable a gradual transition into local society. ${ }^{49}$ Nevertheless, Bristol's police force did implement some positive measures. Through a liaison officer and area constables, it sought to establish closer links with immigrant communities by offering them advice, serving on consultative and social welfare committees and attending immigrant association meetings. ${ }^{50}$

The Council of Christian Churches and the Council of Social Service also turned their attention to the growing Commonwealth immigrant communities. They jointly sponsored the Committee for the Welfare of Colonial Workers in Bristol, a voluntary body established in 1952. Its rationale was to bring together those involved in the settlement of 'coloured' workers in the city, and West Indians specifically. It benefited from the three-year appointment of a colonial liaison officer in 1956 whose task was to conduct research and welfare work, and promote the integration of Bristol's 'coloured' immigrants. ${ }^{51}$ The officer carried out a survey into West Indian family life, provided information on their experiences of migration, settlement, employment, unemployment, housing and residential concentration and served as a bridge between West Indians who encountered difficulties and

\footnotetext{
${ }^{46} \mathrm{BA}, 27155 / 2$, various; $\mathrm{BA}, 27155 / 3$, various.

${ }^{47} \mathrm{BA}$, police liaison officers with coloured populations, West Indians etc., 1953-69 Pol/LG/1/1, various.

${ }^{48} \mathrm{BA}, \mathrm{Pol} / \mathrm{LG} / 1 / 1$, folder 1 , Bristol Constabulary, report by chief superintendent, 'Commonwealth Immigrants Bill', 27 Mar. 1962.

${ }^{49} \mathrm{BA}, \mathrm{Pol} / \mathrm{LG} / 1 / 1$, folder 2, Bristol Constabulary, 'D' Division, report by superintendent, 'Racial discrimination', 2 Jan. 1961; and various.

${ }^{50} \mathrm{BA}, \mathrm{Pol} / \mathrm{LG} / 1 / 1$, folder 2 , letter from chief constable to the town clerk and chief executive officer, 2 Apr. 1969.

${ }^{51} \mathrm{MRU}, 3402 \mathrm{c}$, letter from Rev. John Ragg to town clerk, 'Committee for the Welfare of Colonial Workers in Bristol', 23 Dec. 1958.
} 
agencies that offered support. A working party aimed at promoting the acceptance of 'coloured' people amongst white Bristolians emerged from this work. ${ }^{52}$ Community groups, such as the West Indian Development Council (WIDC) and those represented on the Bristol Multi-Racial Advisory Council, addressed race relations and labour and housing market conditions and opportunities. Indeed, the WIDC played a leading role in organizing the 1963 bus boycott in the city, which forced the Bristol Omnibus Company to end its colour bar. The boycott divided the local Labour Party. Local politician Tony Benn and a few others supported the campaign, yet others took no action to challenge racial discrimination. As Madge Dresser argues, this reflected the local party's councillors and aldermen holding largely 'conservative and parochial' opinions on racial matters. ${ }^{53}$ Furthermore, the 'ugly' nature of the dispute may have led to the city council being more hesitant to engage with, and work to improve, local race relations during subsequent years. ${ }^{54}$

Yet after a somewhat slow start, Bristol's local authority did become more active in implementing migration and integration policies. When the colonial liaison officer's three-year appointment ended in 1959, liaison services for colonial immigrants passed to the city's Welfare Services Department. ${ }^{55}$ Furthermore, at least partially inspired by national-level direction, many municipal committees, departments, representatives and officers progressively recognized the need for policies and strategies to encourage the long-term integration of migrants. During the late 1960s, the local government worked alongside, and through, a Voluntary Liaison Committee (VLC). Established in 1967, the VLC comprised members of Bristol City Council, and worked with the town clerk and representatives from numerous statutory and voluntary organizations and immigrant communities in the city. It appointed a liaison officer who worked to investigate, and help alleviate, problems facing immigrant communities, such as loneliness, racial prejudice and racial discrimination in the workplace, and it engaged in discussions in relation to a range of matters, including English-language classes and facilities for cultural and religious activities. ${ }^{56}$

Further, the city tracked statistics on immigrant schoolchildren, established a language centre for children with little or no English and offered Indian and Pakistani women informal instruction in domestic and other subjects. ${ }^{57}$ In what was at least partly an attempt to disperse immigrant pupils, an inner-city secondary school was closed down. Medical examinations were offered to children in primary

\footnotetext{
${ }^{52} \mathrm{MRU}, 3402 \mathrm{c}$, various.

${ }^{53}$ M. Dresser, Black and White on the Buses: The 1963 Colour Bar Dispute in Bristol (London, 2013), 52.

${ }^{54}$ Ibid.

${ }^{55}$ BA, Welfare Services Committee and Miscellaneous Sub-Committees minute book, 6 Jun. 1957-25 May 1961, M/BCC/WEL/1/5, Welfare Services Committee meeting, 1 Jan. 1959.

${ }^{56}$ BA, Voluntary Liaison: Community Relations Council proceedings, 10 Jan. 1967-19 Jun. 1974, M/ BCC/VLC/1/1, various; BA, Bristol Council of Christian Churches: minutes 1962-71 43077/M/1/4, Bristol Council of Christian Churches meeting, 17 Feb. 1969.

${ }^{57} \mathrm{MRU}$, town clerk files, literature on immigration $3525 \mathrm{c}$, 'The education of immigrant children', chief education officer report, 18 Mar. 1966; BA, (Series A) minutes and reports, 1965-68 21131/EC/Adm/M/4/ 35, Further Education Committee, 17 Jan. 1967; BA, (Series A) minutes and reports, 1968-71 21131/EC/ Adm/M/4/36, Special Sub-Committee of the Education Committee, 23 May 1968.
} 
schools with high percentages of immigrant pupils. ${ }^{58}$ Bristol's local authority frequently discussed and expressed concern about the housing conditions of Indians, Pakistanis and West Indians, especially with regards to multi-occupation, overcrowding, residential segregation and what were perceived to be poor housing and living standards. The Housing Department encouraged immigrants to apply for council housing, but they often preferred to stay together in inner-city areas. ${ }^{59}$ Furthermore, the city investigated the employment experiences of immigrant school-leavers, and there were various reports that highlighted West Indians' parenting practices and financial and welfare problems. Areas and neighbourhoods with high immigrant residency were at times earmarked for either demolition or redevelopment. ${ }^{60}$ On the whole, Bristol witnessed a growing number of state and non-state actors engage with issues of migration and race relations across the post-war decades. Their responses were shaped by a diverse range of factors, from genuine concern about migrant integration to hesitancy and racially prejudicial anxieties and rhetoric.

\section{Malmö}

The period 1945-70, 'the quarter century of labour migration' as it has been called in Swedish historiography, is one of (almost) uninterrupted economic growth and of constant labour shortages in a context of industrial expansion. ${ }^{61}$ After considering other options, both industry and the national government opted to address labour shortages by recruiting workers in other European countries. Malmö, Sweden's third largest city, is an ample example of this development, and the city's largest employer, the Kockums shipyard, was among the first employers to establish recruitment offices in Germany and Italy. Malmö, an industrial city, was seen in Sweden as an example of economic progress, modernity and the promises of the emerging social democratic-led welfare state. Labour migrants were viewed as a way to facilitate continuous economic expansion. The social democratic-led municipality in Malmö mostly abstained from taking part in migrant reception during that time, and it would continue to do so until the late 1960s, leaving industry as the dominant actor in organizing migrant reception by negotiating with trade unions about labour conditions and with landlords to secure housing for new arrivals. However, migrants themselves were also actors in the process, at times protesting poor living conditions and low wages. From 1965, the municipality took a more active role in migrant reception, as it increasingly saw

\footnotetext{
${ }^{58} \mathrm{BA}$, report of medical officer of health and social services of Bristol, 1968-70 33416/32a, principal school medical officer, 1968 report; House of Commons, Home Affairs Committee, Race Relations and Immigration Sub-Committee, racial disadvantage, minutes of evidence, 22 May 1980, Bristol, 3.

${ }^{59} \mathrm{BA}$, Housing Committee minute book, Jul.-Dec. 1964, M/BCC/HOU/1/36b, Housing Committee meeting, 7 Sep. 1964; MRU, 3402c, meeting to discuss the health, housing and welfare of immigrants in Bristol, 4 Nov. 1964; BA, 43077/M/1/4, annual general meeting, 14 Mar. 1966.

${ }^{60} \mathrm{BA}, \mathrm{M} / \mathrm{BCC} / \mathrm{HOU} / 1 / 36 \mathrm{~b}$, Housing Committee meeting, 7 Sep. 1964; BA, M/BCC/VLC/1/1, Bristol Community Relations Council, informal meeting to discuss coloured school leavers and employment, 11 Dec. 1970; BA, 33416/32a, the medical officer of health and social services, 1970 report.

${ }^{61} \mathrm{M}$. Byström and P. Frohnert, Invandringens historia: Från 'Folkhemmet' till dagens Sverige (Stockholm, 2017), 33.
} 
migrants as problems that welfare institutions needed to address. This changed the focus of migrant reception into a project of societal inclusion of migrants with the municipality as the main actor.

The municipality's slow response can be understood partly due to the lack of international migration to the city prior to World War II, when migrants in general travelled from Sweden and Swedes emigrated to the USA in huge numbers, fleeing poverty and harsh labour conditions in rural Sweden. In a marked shift beginning in 1945, about 600,000 labour migrants as well as small groups of refugees arrived in Sweden over 25 years. Young women (mostly German or Danish) seeking domestic work made up the majority of migrants coming to Sweden and Malmö until 1955, but more men arrived as labour shortages in the city's manufacturing industries grew. The national origins of migrants to post-war Malmö were diverse, but their total numbers were low. The only groups in Malmö exceeding 1,000 persons in the national censuses were people born in Denmark, Germany and Poland in the 1950 census and those born in Denmark, Germany, Finland and Yugoslavia in the 1970 census. $^{62}$

As the municipality largely abstained from involvement, local industry was the central actor in migrant reception after World War II and most revelant decisions were made at board meetings rather than in City Hall. The textile industry in Malmö already employed Estonian war refugees during the war, while Kockums shipyard recruited skilled workers from all of Europe, starting in northern Italy in the late 1940s. ${ }^{63}$ Even though there was unemployment in the region at the time, the company struggled to find sufficient numbers of workers with the necessary skillsets but also the discipline perceived to be needed for work at a modern shipyard. As economic historian Joacim Waara has underscored, in addition to remedying labour shortages, the companies had an economic interest in labour migration, as it would increase their competitiveness and lower wage costs. ${ }^{64}$ Hence, they had double incentives to overcome such obstacles, which led Malmö companies to hurry to establish and implement a migrant labour recruitment and settlement programme.

Bypassing the obstacle of housing shortages was another of the local industry's motives for choosing foreign recruitments. A lack of working-class housing and poor living conditions had been among the first issues the Social Democratic Party addressed after coming to national power in the early 1930s, and the local Social Democrats in Malmö initiated large-scale housing projects. These only began in the early 1950s, though, and were not sufficient to fill contemporary needs. ${ }^{65}$

\footnotetext{
${ }^{62}$ Byström and Frohnert, Invandringens historia, 33-40; E. Strollo, Det städade folkhemmet: Tyskfödda hembiträden i efterkrigstidens Sverige (Gothenburg, 2013), 19-20; J. Svanberg, Migrationens kontraster: Arbetsmarknadsaktioner, Schleswig-Holsteing-aktionen och tyskorna vid Algots i Borås under 1950-talet (Lund, 2016), 13-14; A. Järtelius, Bortastaden: Kommunalt invandrarmottagande i Malmö 1966-1997 (Malmö, 2000), 29; Folkräkningen den 31 december 1950 (Stockholm, 1952-56); Folk- och bostadsräkningen 1970 (Stockholm, 1972).

${ }^{63}$ J. Lundin, Malmö industristaden: Addo, Cementa, Ljungmans, Kockums (Malmö, 2007), 21.

${ }^{64}$ Byström and Frohnert, Invandringens historia, 45-9; J. Waara, Svenska arbetsgivareföreningen och arbetskraftsinvandringen 1945-1972 (Gothenburg, 2012), 23-4, 154-9.

${ }^{65}$ Swedish Government Official Reports 1945:63, Bostadssociala utredningen, Slutbetänkande; M. Grander, 'New public housing: a selective model disguised as universal? Implications of the market adaptation of Swedish public housing', International Journal of Housing Policy, 17 (2017), 335-52.
} 
Already in the 1940s, local industry viewed the improvement of workers' housing, especially for workers with families, as strategically important to solve long-term labour shortages. Consequently, corporate boards collaborated with each other, state authorities, local landlords and construction companies to create more and better housing in order to attract the necessary labour. ${ }^{66}$ It proved hard, however, to secure housing for families, while the wooden barracks where migrant workers were lodged in the 1940s were easier to install. Companies struggling with labour shortages could not wait years for the housing programme to bear fruit, so they recruited foreigners who were willing to live in barrack conditions in the meantime. The textile manufacturer MAB \& MYA utilized existing infrastructure to offer temporary housing to new employees near the factories located on the southern outskirts of Malmö. For the Estonian war refugees arriving during the war, barracks were built in the same area. ${ }^{67}$ Kockums lodged Italian workers in barracks on the borders of the Bulltofta airfield, bordering the working-class district of Kirseberg, home to a growing migrant population from the 1950s. One of the houses in the neighbourhood was named 'the Macedonian embassy', adding to an older vernacular of 'the gypsy valley' for a neighbourhood park. Such language indicates that migrants were given housing in areas already stigmatized in racialized terminology. ${ }^{68}$

Migrant groups protested against their conditions at times. An example is a wildcat strike at Kockums in 1948 by Italian metal workers, who were frustrated with low housing quality and salaries. As their grievances were neither remedied nor acknowledged by the Swedish trade union, the workers took strike action and managed to improve their conditions. ${ }^{69}$ Although Swedish workers at Kockums had participated in a large strike only a few years earlier, the corporate board interpreted the wildcat strike as an expression of the Italians' cultural particularity, and the company repeatedly referred to the strike as a negative experience when planning for further recruitment of migrant workers. ${ }^{70}$

The municipality was selective in its support for migrant groups, and most often chose not to be involved in their community building. For example, in 1957 a request for a Jewish crèche was declined, even though the municipality had granted a request for support for an Estonian crèche in $1948 .^{71}$ In their rejection, the municipal bureaucracy stated that childcare should be informed by democratic principles rather than providing a racially and religiously particularist upbringing, suggesting an assimilationist approach. Some migrant groups launched organizations without requesting municipal assistance and while these organizations were likely important

\footnotetext{
${ }^{66}$ Malmö stadsarkiv (MS), Kockums mekaniska verkstads AB (KMV AB), A1A Styrelseprotokoll, various.

${ }^{67}$ A. Sarnäs and K. Sjöberg (eds.), På gränsen mellan krig och fred: Minnesbilder från Malmö 1939-1945 (Malmö, 2015), 125-30; MS, MAB och MYA aktiebolag, F1A:3 Handlingar rörande personalbostäder.

${ }^{68} \mathrm{M}$. Ericsson, Exkludering, assimilering eller utrotning? 'Tattarfrågan' $i$ svensk politik 1880-1955 (Lund, 2015), 148-9; H. Swedner, Invandrare i Malmö. Forskningsrapport från invandrarutredningen (Stockholm, 1973), 139.

${ }^{69}$ C. Tirone, 'En italienare kommer till Kockums', in L. Olsson and C. Hult (eds.), Arbetets historia: Föreläsningar i Lund 3 (Lund, 1989), 97-108.

${ }^{70}$ MS, KMV AB, A1A Styrelseprotokoll, 1 Feb. 1950.

${ }^{71}$ MS, Drätselkammaren i Malmö 1863-1970 (DM), AI, Ärende 387, protokoll 16 Jun. 1948; MS, DM, AI, Ärende 425, protokoll 9 Sep. 1957.
} 
providers of information and social support for arriving individuals, they were not invited to become part of the local governance of migrant reception. ${ }^{72}$

Developments from the mid-1960s led the municipality to become the leading actor in local migrant reception. One such development was the general tendency of Swedish municipalities in the 1960s to start performing more functions of the expanding welfare state. ${ }^{73}$ At the same time, in response to public debates on the conditions migrants and minorities faced in Sweden, the national government started to prepare an immigrant policy. ${ }^{74}$ When staged in local newspapers in Malmö, the debate concerned migrants from Yugoslavia. ${ }^{75}$ Over the course of a few years in the mid-1960s, Yugoslavs became the largest group of foreign citizens living in Malmö following a new bilateral agreement between Sweden and Yugoslavia in 1964. Since the arrival of this migrant group coincided with an economic recession, many migrants from Yugoslavia found it hard to obtain employment and housing, forcing the municipality to cater for their welfare. ${ }^{76}$

During these years, municipal policy was in flux and different municipal actors expressed changing ideas about what and how much the city should do. In 1965, the city's Social Welfare Department depicted the cost of aiding migrants as 'a crisis that we cannot control', ${ }^{77}$ connecting with a small but alarmist popular opinion emphasizing the magnitude of the problems. This idea of an uncontrollable crisis was contested during the following years. At the beginning of 1967, two social democratic deputies motioned that Malmö should develop a programme for aiding immigrants' adaptation. When commenting on the motion, Malmö's Social Welfare Committee contradicted the statement made by its department two years before, claiming that: '[S] ocial assistance is provided in very small amounts in individual cases. The often-stated suggestion that foreign citizens more or less often exploit Swedish social benefits is grossly inaccurate. ${ }^{, 78}$ As a result of the motion, Malmö's Social Welfare Committee commissioned a report in 1967, titled Yugoslavs in Malmö. The report is a key document in the development of the municipality's migrant reception policy, as it was the most coherent and elaborated articulation of the city grappling with its role in migrant reception in the period under examination. The report rebuts the claim that Yugoslav migrants were overusing economic resources, and shows that they were exposed to discrimination from authorities in the housing sector and labour market. ${ }^{79}$ While the report describes discrimination and institutional racism and negates the racist trope of a 'crisis' created by migration that threatens the welfare state, it at the same time

\footnotetext{
${ }^{72}$ Swedner, Invandrare i Malmö, 246-54.

${ }^{73}$ L. Nilsson and H. Forsell, 150 år av självstyrelse: Kommuner och landsting $i$ förändring (Stockholm, 2013), 158.

${ }^{74}$ Byström and Frohnert, Invandringens historia, 42-5.

${ }^{75}$ G. Behring-Andersson, 'Utländska arbetssökande tas emot med armbågen', Arbetet, 18 Aug. 1965; L. Genell-Harrie, 'Ta emot nykomlingar', Arbetet, 4 Feb. 1965; L.-O. Borglid, 'En klibbig massa av hat', Arbetet, 8 Mar. 1966; L.-O. Borglid, 'Olösta problem', Arbetet, 10 Mar. 1966; H. Widing, 'Biljetterna var nitlotter', Sydsvenska Dagbladet, 25 Jan. 1966.

${ }^{76}$ Byström and Frohnert, Invandringens historia, 40-3; Järtelius, Bortastaden, 44.

${ }^{77}$ Quote from Järtelius, Bortastaden, 41.

${ }^{78}$ Quote from ibid., 42.

${ }^{79}$ K. Belfrage, Jugoslaver i Malmö (Malmö, 1967).
} 
depicts racism in an ambivalent manner as a problem that might evolve from encounters with migrants, rather than being inherent to Swedish society. ${ }^{80}$

All in all, Yugoslavs in Malmö presents 'immigrant adaptation' as a social problem, one which the municipal welfare institutions could handle very well. The report points out language training and community information as two factors that would best facilitate immigrants' adaptation. ${ }^{81}$ On the basis of these findings, the municipality began collaborating with Folksuniversiteit, one of the local statefunded civil society providers of Swedish courses for immigrants, whose teachers were already serving as suppliers of community information in between classes. Their work became the model for the municipal Immigrant Service Office, which opened in 1968, representing a clear break with the city's earlier non-policy position. Hence, in Malmö, the main focus of migrant reception changed from finding housing and supplementing basic needs for migrants in 1945 with industry as the main actor, to a municipal project of societal inclusion of migrants starting in the late 1960s.

\section{Analysis}

To structure our comparative analysis of how our three cities reacted to migration, we rely on a definition of local governance from the recently published Handbook of the Governance of Migration and Diversity in Cities. According to the editors, the urban governance of migration and diversity unfolds at the intersection of: (1) legacies of migration histories, (2) specific policies formulated from the top-down and bottom-up, (3) policy networks and (4) city identities constructed in relation to migration. ${ }^{82}$ We find it fruitful to combine points (1) and (4) into a single analytical category, city histories and identity, and (2) and (3) into the category of urban policies as outcomes of horizontal and vertical interactions. Caponio's aforementioned term, 'local policy arenas', is most appropriate for capturing this second category. We compare the urban governance of migration across the three cities by considering how city histories and identities intersect with local policy arenas to influence the attitudes and policies of municipal actors. In doing so, we highlight and compare temporal shifts in the local governance of migration from the late 1940s to the late 1960s, and demonstrate how municipalities and semi- and non-state actors engaged with migration reception processes.

Regarding the first category, urban identities rooted in historical discourses are essential to understanding why the governance of migration and diversity unfolded differently across the three cities. In Dortmund, officials embraced a 'melting-pot' identity already during the 1950s as a strategy for integrating new populations of expellees and refugees. They consciously drew upon regional and city history in which Dortmund, a small town before the mid-nineteenth century, received large

\footnotetext{
${ }^{80} \mathrm{Ibid}$., 8-11, 17-21, 24-3, 150. For analyses of Swedish society's refusal to address its racialized social structure, see P. de los Reyes, I. Molina and D. Mulinari (eds.), Maktens (o)lika förklädnader: Kön, klass é etnicitet $i$ det postkoloniala Sverige (Stockholm, 2002); L. Brännström, "Ras" i efterkrigstidens Sverige: Ett bidrag till en mothistoria', in T. Hübinette and A. Wasniowski (eds.), Studier om rasism: Tvärvetenskapliga perspektiv på ras, vithet och diskriminering (Malmö, 2018).

${ }^{81}$ Belfrage, Jugoslaver i Malmö, 12-16.

${ }^{82}$ Caponio, Scholten and Zapata-Barrero, 'Introduction', 6.
} 
amounts of migrants from other parts of Germany and Poland during its rapid industrialization. It was a salient part of city identity, but it was the choice of key municipal actors - the mayor, the city archivist, the city manager - to invoke this history to normalize the large-scale migrant presence in Dortmund during reconstruction. In comparison, despite its history as a major port, maritime centre and gateway between Britain and the world, Bristol often displayed the same uncertainty and apprehension regarding post-war 'coloured' immigration as other British cities. Furthermore, Bristol had experienced the arrival of diverse migrant groups since the medieval period, and was already home to a black population by the sixteenth century. Yet it was arguably the legacy of its participation in the slave trade, colonialism and the accompanying racist ideology that shaped some attitudes vis-à-vis West Indian migrants especially, thus creating a sense of anxiety and unease amongst some local actors. ${ }^{83}$ Though Malmö, similar to Dortmund, experienced rapid urbanization around 1900, this did not translate into any kind of migration city identity. Those who moved to Malmö, mostly from rural southern Sweden, did not appear culturally different in the way that Poles and Eastern Germans did in Dortmund's corresponding migration process. It was only after World War II that Malmö became home to a growing number of international refugees and labour migrants. The legacy left by this lack of historical experience with immigration shaped the city's post-war governance of migration, which was frequently characterized by hesitant and incoherent policies.

These differing legacies and interpretations of migration histories, and corresponding urban identities, influenced when and how municipal officials acknowledged their cities as migration cities, and began to play active roles in migrant reception policies and practices. Dortmund's municipality took a leadership role in migrant integration during the post-war reconstruction crisis, and it later extended its welcoming discourses and open concept of city-citizenship to guest workers. After assuming more of a role in providing liaison services for colonial immigrants, thereby continuing the work of a local voluntary committee, Bristol's local authority gradually became more active in devising and implementing migrant policies during the 1960s. Similarly, encouraged by a growing perception that the increasing number of labour migrants settling in the city was fomenting a crisis situation, Malmö's government also became active in responding to migration during the 1960s through its Social Service Department. Indeed, the special branch of local government that was created in 1968 to manage immigrant reception reflected a major increase in the municipality's ambition.

The cities' identity constructions also shaped local concepts of belonging, and the perceived place and role of migrants in local society. This resulted in some migrant groups being perceived as more deserving than others, and gaining greater access to a sense of local citizenship and belonging. As Malmö officials did not consider their city a migration city, some immigrants were treated as outsiders, 'guests' in a country that did not have official guest-worker programmes. Whereas certain groups, such as Danes and Germans, were considered unproblematic, Italians gained a negative reputation as troublemakers after a 1948 wildcat strike.

\footnotetext{
${ }^{83}$ The argument that Bristol's connection with slavery shaped some attitudes towards post-war Caribbean immigrants in the city has been made elsewhere. See Dresser and Fleming, Bristol, 222.
} 
Yugoslav labour migrants in the 1960s, whose arrival coincided with an economic recession that encumbered their labour market participation, were likewise seen as experiencing problems 'adapting' to Swedish society. The municipality, however, came to the conclusion that municipal welfare systems could address the problems these migrants were facing. In the process, new agencies such as the 'Immigrant information' service and language-training were introduced. Whereas this represented a shift in Malmö's local governance of migration, Dortmund, which was harder hit by the 1966-67 recession, exercised policy continuity. Dortmund officials appealed to the public to show understanding for difficulties experienced by laid-off guest workers and said that they could stay if they participated in vocational training, had family in Dortmund or had an occupational disability.

In Bristol, the circumstances of some migrants' arrival mixed with racial discrimination and prejudice to shape certain attitudes and responses they encountered. Refugees and DPs often arrived through official schemes and provisions, and were seen to be in need by the community, religious and voluntary organizations that assisted their settlement. By contrast, although 'coloured' Commonwealth immigrants also benefited from the support of such organizations, some local actors portrayed them as posing challenges due to their perceived inferior morals and social behaviour, poor living and welfare conditions and parenting practices. Such concerns developed especially regarding West Indians whose growing numbers in inner-city areas were a source of some anxiety, and whose integration was frequently seen as difficult. Dortmund officials did not distinguish between migrant groups in this way. The fact that expellees and refugees had specific legal rights accorded by occupation, state and federal authorities allowed Dortmund officials to externalize responsibility for the privileging of certain groups to urban housing and other city services. The overt discrimination municipal officials practised between migrants was skill- and occupation-based; Dortmund wanted qualified workers to fill its refugee quotas in the 1940s-50s and wanted to dissuade guest workers from bringing family members with them in the 1960s. Even when refugees refused low-status jobs, municipal authorities did not attempt to force them as this was contrary to democratic values. When de-industrialization hit, Dortmund's Labour Office presented unemployed guest workers as unwitting victims of the crisis. Thus, Dortmund's local migration city identity prevailed, resulting in official depictions of expellees, refugees and later guest workers as willing and able to work and integrate.

In addition to city histories and identities, a series of horizontal and vertical interactions shaped local migration policy-making during the post-war decades. In Malmö, local industry was initially responsible for the governance of migration, which reflected Sweden's post-war migration-policy paradigm more broadly. Given that refugees who arrived towards the end of World War II were considered potential labourers, individual company boards managed housing provision and eschewed interaction with local migrant associations and other civil society organizations. It was not until the mid-1960s, upon realizing that the labour market and its institutions could no longer handle the issue, that Malmö's municipality took the lead in the governance of local migration. Bristol's local migration arena was somewhat more complex. Initially, an assortment of largely charitable, community, religious and voluntary organizations often drove the city's response to migrants 
and refugees, no doubt partially filling a void until Bristol's government became more active in devising and implementing migration policies and practices during the 1960s. Furthermore, they continued to respond to migrant communities throughout the 1960s, often working in collaboration with, and alongside, Bristol's municipality.

In comparison to Malmö and Bristol, Dortmund's local government was proactive from the outset, leading the city's response to expellee and refugee settlement, while companies like Hoesch shared responsibility for housing labour migrants with the city. When guest workers arrived in the 1960s, there was a local division of labour, as recruiting companies took charge of housing and the city promoted social inclusion. Like in Bristol and Malmö, Dortmund officials relied on local organizations and non-state actors but they were stronger than their counterparts in structuring the contours of their engagement in the local policy arena. Christian charities were charged by the municipality with the reception of refugee youth, heavy industry companies provided housing and Arbeiterwohlfahrt co-funded the Turkish cultural centre. Nevertheless, it was the municipality that led efforts to turn Dortmund's post-war identity as a migration city into concrete political practice. Whilst non-state actors and stakeholders constituted subordinated elements of Dortmund's local migration governance, it proves difficult to envisage an initial local response to migration and diversity in post-war Malmö and Bristol without them.

Vertical relationships with national-level policy frameworks also influenced migration policy-making in all three cities. In Malmö, the municipality's increased activity during the late 1960s partly resulted from historic changes in Swedish policy that gave municipalities more active roles in the general welfare programme. This, combined with the launch of an ambitious national housing programme to subsidize local housing initiatives, greatly expanded the governing capacity of Malmö's bureaucracy to engage with migrant communities. Local influences then directly influenced national developments, as policy shifts in Malmö were instrumental in the construction of a new national policy on migrant integration in the 1970s. The community, religious and voluntary organizations that played crucial roles in Bristol's response to migrants and refugees in the 1950s and 60s were often local divisions of national organizations. Similarly, the Voluntary Liaison Committee with, and through, which Bristol's municipality worked was one of many established across the country to promote local-level integration. More broadly, Bristol's response to South Asians and West Indians played out against, and was no doubt shaped by, nationwide anxieties and concerns about the settlement and integration of non-white Commonwealth immigrants and the potential disruption they posed to British society.

Partly reflecting Germany's federal system, Dortmund displayed more vertical fragmentation between national and local levels than Bristol and Malmö. Nevertheless, it frequently found itself reacting to federal policies and decisions. Dortmund's policies have to be understood within the context of a deeply unwelcome situation foisted upon the city - by the federal and state governments but more broadly by the legacy of Nazi destruction. This sentiment fed into the city's integrative narration of Dortmund as a community of suffering. Top-down funding both enabled and restricted city ambitions: the municipal housing 
programme was partly dependent on federal funding. It had to tighten its belt from 1960 as federal and state reconstruction subsidies ended. Nonetheless, the city demonstrated impressive leadership on migration reception and integration despite, or perhaps because of, its protacted post-war reconstruction crisis, and it carried this leadership role into the 1960s.

Our article has presented a cross-city, cross-country comparison of migrant reception policies and practices in three post-war European cities. Beyond the comparison itself, its contributions to the field of urban migration studies are threefold. Firstly, our findings demonstrate the potential of history to contribute new perspectives for social-science research on local migration governance. History should gain more prominence in analyses of urban societies and migration because it is critical in shaping understandings of city identity affecting how local actors respond to migration. Secondly, the article shows how local perspectives cast new light on national migration historiographies by highlighting the pioneering role of Malmö in shifting Sweden's migration paradigm, the local dimensions of race relations in Bristol and local and regional variation in post-war Germany. As we analyse elsewhere, post-war case-studies also contribute to European migration history more broadly because (dis)continuities between post-war and later forms of migration remain largely unexplored. ${ }^{84}$ Thirdly, we have developed a comparative methodology for urban migration history that builds on social-science research on local migration governance. Conceptualizing urban migration policy and practices as intersections of (1) city histories and identities and (2) local policy arenas and national-local interactions, we argue, is a promising path forward for urban historians interested in exploring what is unique in their city histories and what reflects wider national and temporal trends in migration history.

\footnotetext{
${ }^{84}$ B. Shaev and S. Hackett, 'Cities, migration and the historiography of postwar Europe', Journal of Migration History, 7 (2021), 191-219.

Cite this article: Shaev B, Hackett S, Brunnström P, Nilsson Mohammadi R (2022). Refugees, expellees and immigrants: comparing migrant reception policies and practices in post-war Bristol, Dortmund and Malmö. Urban History 1-20. https://doi.org/10.1017/S0963926821001048
} 